веществ рационов нетелями // Аграрный научный журнал. - 2017. - № 12. - С. 42-45.

9. Прытков Ю.Н., Кистина А.А., Червяков М.Ю. Эффективность применения хвойно-энергетической кормовой добавки в молочном скотоводстве // Аграрный научный журнал. - 2015. - № 10. - С. 17-20.

10. Червяков М.Ю., Прытков Ю.Н., Кистина А.А. Влияние разных дозировок хвойно-энергетической кормовой добавки в рационе на динамику живой массы и среднесуточных приростов нетелей // Ресурсосберегающие экологически безопасные технологии производства и переработки сельскохозяйственной продукции: сб. статей. - Саранск, 2016. - С. 74-76.

11. Червяков М.Ю., Кистина А.А., Прытков Ю.Н. Влияние хвойно-энергетической добавки на экстерьер нетелей // Механизмы и закономерности индивидуального развития человека и животных: материалы IV Междунар. науч.-практ. конф., 15-16 ноября, 2017. - Саранск. - С. 389-303.

12. Prytkov Y.N., Kistina A.A., Korotkiy V.P., Ryzhov V.A., Roshchin V.I. Biological substantiation of ap- plication of the coniferous-energy supplement in feeding of heifers // Joumal of Phanmaceuticol Sciences and Research, 2017, T. 9, No. 6. - C. 817-821.

Прытков Юрий Николаевич, $\partial-p$ c.-х. наук, проф. кафедры зоотехнии им. профессора С.А. Лапшина, Наииональный исследовательский Мордовский государственный университет имени Н.П. Огарева. Россия.

Кистина Анна Александровна, $\partial-p \quad c .-x$. наук, проф. кафедры зоотехнии им. профессора С.А. Лапшина, Национальный исследовательский Мордовский государственный университет имени Н.П. Огарева. Россия.

Дорожкина Екатерина Ивановна, аспирант кафедры зоотехнии им. профессора С.А. Лапшина, Наицональный исследовательский Мордовский государственный университет имени Н.П. Огарева. Россия.

430904, г. Саранск, ул. Российская, 37.

Тел.: (8342) 25-41-65.

Ключевые слова: хвойно-энергетическая добавка; рацион; корма; живая масса; среднесуточные приросты; телята; гематологические показатели.

\title{
APPLICATION OF THE CONIFEROUS-ENERGY ADDITIVE IN THE FEEDING OF YOUNG CATTLE
} IN THE DAIRY GROWING PERIOD

Prytkov Yuriy Nikolaevich, Doctor of Agricultural Sciences, Professor of the chair "Zootechnics named after Professor S.A. Lapshin", National Research Mordovia State University named after N.P. Ogarev. Russia.

Kistina Anna Aleksandrovna, Doctor of Agricultural Sciences, Professor of the chair "Zootechnics named after Professor S.A. Lapshin", National Research Mordovia State University named after N.P. Ogarev. Russia.

Dorozhkina Ekaterina Ivanovna, Post-graduate Student of the chair "Zootechnics named after Professor S.A. Lapshin", National Research Mordovia State University named after N.P. Ogarev. Russia.
Keywords: coniferous-energy additive; ration; feed; live weight; average daily increments; calves; hematological indices.

In the article results of application in a ration of young cattle of a coniferous-energy additive are considered. The dosage of the coniferous-energy additive at the rate of $30 \mathrm{~g}$ per head per day proved to be the most effective and contributed to an increase in digestibility of nutrients and the use of mineral elements and an increase in live weight and average daily growth.

\section{ПРЕПАРАТ «ЛЕКСОФЛОН» ДЛЯ ЛЕЧЕНИЯ КОРОВ ПРИ ХРОНИЧЕСКОМ ГНОЙНО-КАТАРАЛЬНОМ ЭНДОМЕТРИТЕ}

\author{
СЕМИвоЛОС Александр Мефодьевич, Саратовский государственный аграрный \\ университет имени Н.И. Вавилова
}

КАШКОВСКАЯ Людмила Михайловна, Саратовский государственный аграрный университет имени Н.И. Вавилова

ПАНКОВ Иван Юрьевич, ООО «Нита-Фарм»

БРЮХАНОВА Анастасия Андреевна, Саратовский государственный аграрный университет имени Н.И. Вавилова

\begin{abstract}
Представлены результаты исследований по применению препарата «Лексофлон» коровам, больным хроническим гнойно-катаральным эндометритом. Наиболее эффективным для лечения животных оказалось внутримышечное введение препарата в дозе 1 мл/10 к2 массы тела с интервалом 3 дня. Клиническое выздо-

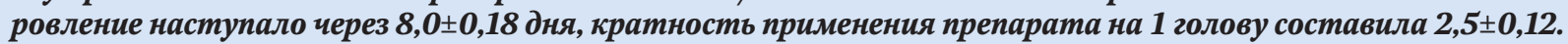

Введение. Одна из существенных проблем молочного скотоводства, влияющих на эффективное развитие отрасли, - заболевания матки воспалительного характера $[3,8]$. Острые формы эндометритов регистрируются у $17,73 \%$ коров, а на долю хронических эндометритов приходится 10,94-14,03 \% от общей акушерско-гинекологической патологии [9]. По мнению ученых, основной причиной возникновения воспаления слизистой оболочки матки является инфицирование репродуктивных органов условно-патогенной микрофлорой [5]. Микробиологическими исследовани- ями экссудата установлена контаминация полости матки стафилококками, эшерихиями, протеями, псевдомонами и грибами $[2,10]$. Возникновение эндометритов у коров связывают также с нарушением миотропной функции миометрия [4]. Хронические эндометриты наносят большой экономический ущерб молочному скотоводству, поскольку коровы не проявляют половой цикличности, остаются бесплодными длительное время, снижается молочная продуктивность животных.

Наиболее распространенным методом лечения коров при острых и хронических эндометритах 
считается внутриматочное введение лекарственных препаратов, обладающих антимикробным действием [6, 7]. Е.В. Громыко [1] указывает на высокую эффективность трехкратного внутриматочного введения препаратов «Комплексан» и «Поливет». Используя суппозитории ветомгина для лечения коров с гнойно-катаральным хроническим эндометритом, удалось повысить оплодотворяемость коров на $25 \%$ и снизить сервис-период на 31,7 и 45,0 дня [12]. Однако при хроническом эндометрите в отличие от острых форм просвет цервикального канала открыт незначительно, поэтому внутриматочное введение препаратов в виде свечей, таблеток довольно проблематично, особенно при повторном применении, что не позволяет добиться полного клинического выздоровления животных.

Цель данной работы - изучение терапевтической эффективности лекарственного препарата «Лексофлон» для лечения коров при хроническом гнойно-катаральном эндометрите

Методика исследований. Исследования проводили на базе СПК «Колхоз Красавский» Лысогорского района Саратовской области и на кафедре «Болезни животных и ветеринарно-санитарная экспертиза» ФГБОУ ВО Саратовский ГАУ им. Н.И. Вавилова. В опыт были включены коровы симментальской породы средней упитанности с 5-7-летнего возраста продуктивностью 3254-4564 кг молока за лактацию. Диагноз на заболевания репродуктивных органов у коров ставили на основании анализа первичного зоотехнического учета, результатов вагинального и ректального исследований. Содержимое матки при хроническом гнойно-катаральном эндометрите коров для исследования на наличие микрофлоры и определение ее чувствительности к различным лекарственным препаратам проводили в ГНУ ВНИВИ Россельхозакадемии (г. Саратов).

По принципу аналогов сформировали 3 опытные и одну контрольную группы коров, больных хроническим гнойно-катаральным эндометритом, по 5 голов в каждой. Применение различных препаратов при хроническом гнойно-катаральном эндометрите осуществляли по схеме, представленной в табл. 1. Введение препарата «Лексофлон» коровам опытных групп выполняли подкожно, внутримышечно. Препарат вводили, не используя цервикальный канал, различными способами и в разных дозировках, согласно требованиям, установленным к испытанию новых лекарственных средств. Действующим веществом препарата «Лексофлон» является левофлоксацин (150 мг в 1 мл препарата) [11]. Для лечения коров контрольной группы использовали препарат «Ветбицин-3», который широко применяется при данной патологии. Признаки клинического выздо- ровления коров разных групп отмечали в первые 10 дней эксперимента, а наблюдения за животными осуществляли в течение 30 дней: учитывали проявление половой цикличности, количество использованных доз препаратов. Ректальное исследование на беременность проводили через 60 дней после искусственного осеменения самок.

Полученные результаты подвергали биометрической обработке с определением степени достоверности имеющихся различий.

Результаты исследований. Экспериментальные исследования показали, что значительное место среди акушерско-гинекологической патологии занимали хронические эндометриты (7,69 \%). Это больше чем распространение катаральной и гнойной форм острых послеродовых эндометритов. Хроническая форма течения эндометрита характеризовалась незначительным выделением экссудата из полости матки. Он выделялся, как правило, в ночное время, когда животные отдыхают, мускулатура расслабляется, приоткрывается шейка матки. Экссудат выделялся обычно в количестве 50-150 мл. Рога матки были заметно увеличены (в 1,5-2 раза) и имели более плотную консистенцию. Ригидность была резко снижена или отсутствовала совсем.

Установлено, что микрофлора содержимого матки коров с хронической гнойно-катаральной формой эндометрита чувствительна к таким препаратам, как «Лексофлон», «Сепранол», «Нитокс 200» и «Ветбицин-3». Это и определило выбор препаратов для проведения клинических испытаний по установлению их сравнительной терапевтической эффективности. В 1-й и 2-й опытных группах, где для лечения использовали препарат «Лексофлон», клиническое выздоровление наступало у всех животных. Причем во 2-й опытной группе, при несколько более продолжительном сроке выздоровления животных, препарата для лечения потребовалось в 2,8 раза меньше. После применения препарата «Лексофлон» в 3-й опытной группе (5 гол.) выздоровление наступило у 3 животных (40\%), табл. 2 .

Динамика выздоровления характеризовалась сначала уменьшением, а затем и полным прекращением выделения экссудата через 2-3 суток и последующим уменьшением размеров матки, повышением ригидности миометрия. При пальпации к 5-10-му дню рога матки имели одинаковые размеры, четко выраженную межроговую борозду и упруго-тестоватую консистенцию, что свидетельствовало о клиническом выздоровлении коров при данной форме эндометрита. В контрольной группе клиническое выздоровление регистрировали только у 40 \% коров, что на $60 \%$ ниже по сравнению с 1-й и 2-й опытными группами и на $20 \%$ по сравнению с 3-й опытной группой.

Таблица 1

Схема опыта

\begin{tabular}{|c|c|c|c|c|c|}
\hline Группа & Препарат & Способ введения & Доза & Кратность & Примечание \\
\hline 1-я опытная & «Лексофлон» & Внутримышечно & 1 мл/30 кг массы тела & $3-5$ дней & Курс терапии зависит от динамики выздоровления \\
\hline 2-я опытная & «Лексофлон» & Внутримышечно & 1 мл/10 кг массы тела & Однократно & При необходимости инъекцию повторить через 3 суток \\
\hline 3-я опытная & «Лексофлон» & Подкожно & $\begin{array}{l}12,5 \text { мл на } 100 \text { кг } \\
\text { массы тела }\end{array}$ & Однократно & \\
\hline Контрольная & «Ветбицин-3» & Внутримышечно & $\begin{array}{l}10000-15000 \text { ЕД } \\
\text { на } 1 \text { кг массы тела }\end{array}$ & $\begin{array}{l}\text { Один раз в сутки до закры- } \\
\text { тия цервикального канала }\end{array}$ & При необходимости инъекцию повторить через 3 суток \\
\hline
\end{tabular}


Таблица 2

Результаты лечения коров при хроническом эндометрите различными методами $(\boldsymbol{n}=\mathbf{5})$

\begin{tabular}{|r|c|c|c|c|}
\hline \multirow{2}{*}{ Группа Препарат } & \multicolumn{2}{|c|}{ Выздоровело } & $\begin{array}{c}\text { Срок выздо- } \\
\text { ровления }\end{array}$ & $\begin{array}{c}\text { Количество } \\
\text { доз препарата }\end{array}$ \\
\cline { 2 - 5 } & гол. & $\%$ & дни & на 1 гол. \\
\hline 1-я опытная («Лексофлон») & 5 & 100 & $6,6 \pm 0,24$ & $7,0 \pm 0,32$ ** \\
\hline 2-я опытная («Лексофлон») & 5 & 100 & $8,0 \pm 0,18$ & $2,5 \pm 0,12^{*}$ \\
\hline 3-я опытная («Лексофлон») & 3 & 60 & $8,5 \pm 0,31$ & $1,0 \pm 0,0 *$ \\
\hline Контрольная («Ветбицин-3») & 2 & 40 & $8,0 \pm 0,25$ & $3,0 \pm 0,08$ \\
\hline
\end{tabular}

${ }^{*} P<0,05$; ** $P<0,01$.

Срок лечения коров при хроническом эндометрите оказался самым коротким в 1-й опытной группе, где применяли препарат «Лексофлон» 6,6 $\pm 0,24$ дня, а самым продолжительным в 3-й

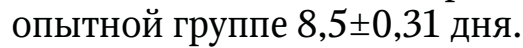

Следовательно, использование препарата «Лексофлон» (на основе фторхинолонов) при лечении коров с хроническим эндометритом более эффективно по сравнению с препаратом «Ветбицин-3».

Заключение. По результатам исследований наиболее эффективным оказалось лечение коров с хронической гнойно-катаральной формой эндометрита препаратом «Лексофлон» при внутримышечном введении в дозе 1 мл/10 кг массы тела животного с интервалом 3 дня. Внутримышечный способ введения лекарственного препарата значительно удобнее и проще по сравнению с внутриматочным.

\section{СПИСОК ЛИТЕРАТУРЫ}

1. Громыко Е.В. Лечение и профилактика эндометрита у коров. - Краснодар, 2008. - 22 с.

2. Калашников B.A. Определение чувствительности к антибиотикам микрофлоры, выделенной из половых путей больных эндометритом коров // Ветеринарная медицина. - 2004. - Вып. 83. - С. 107-110.

3. Коба И.С., Решетка М.Б., Дубовикова М.С. Распространение острых и хронических эндометритов у коров в сельскохозяйственных организациях Краснодарского края // Вестник Алтайского государственного аграрного университета. - 2016. - № 2 (136). - С. 103-106.

4. Кузьмич Р.Г. Проблемы акушерской и гинекологической патологии у коров в хозяйствах Республики Беларусь и некоторые вопросы её этиологии // Современные проблемы ветеринарного обеспечения репродуктивного здоровья животных: материалы Междунар. науч.-практ. конф., посвящ. 100-летию со дня рождения проф. В.А. Акатова. - Воронеж, 2009. - С. 239-244.

5. Медведев Г.Ф., Гавриченко Н. Причины, диагностика, лечение и профилактика метритного комплекса // Ветеринарное дело. - 2013. - № 10. - С. 37-40.

6. Михалев В.И. Принципы рациональной фармакотерапии послеродовых осложнений у коров // Современные проблемы ветеринарного акушерства и биотехнологии воспроизведения животных: материалы Междунар. науч.-практ. конф., посвящ. 85-летию со дня рождения проф. Г.А. Черемисинова и 50-летию создания Воронежской школы ветеринарных акушеров. - Воронеж, 2012. - С. 328-332.

7. Новый препарат для лечения и профилактики эндометритов у коров / М.В. Назаров [и др.] // Теоретические и практические аспекты возникновения и развития болезней животных и защита их здоровья в современных условиях: материалы Междунар. конф. Воронеж, 2000. - Т 1. - С. 165-166.

8. Петров А.М., Мирзахметов Ш.Р. Лечение коров, больных хроническим гнойно-катаральным эндометритом и кистой яичника // Актуальные проблемы болезней органов размножения и молочной железы у животных. - Воронеж, 2005. - С. 139-145.

9. Семиволос А.М., Панков И.Ю. Распространение акушерско-гинекологической патологии у коров в хозяйствах Саратовской области // Аграрные конференции. - 2017. - Вып. 5. - С. 14-18.

10. Семиволос А.М., Агольциов В.А., Панков И.Ю. Видовой состав микрофлоры матки коров при хроническом эндометрите и ее чувствительность к антибактериальным препаратам // Научная жизнь. - 2018. № 2. - С. 101-108.

11. Семиволос А.М., Кашковская Л.М. Новый препарат «Лексофлон» для лечения коров при остром послеродовом эндометрите // Аграрный научный журнал. - 2019. - № 1. - С. 63-66.

12. Фармакопрофилактика и фармакотерапия при гинекологических заболеваниях у коров с использованием пробиотиков / Г.А. Ноздрин [и др.]. - Новосибирск, 2003. - 27 с.

Семиволос Александр Мефодьевич, $\partial-p$ вет. наук, проф. кафедры «Болезни животных и ветеринарносанитарная экспертиза», Саратовский государственный аграрный университет имени Н.И. Вавилова. Россия.

Кашковская Людмила Михайловна, канд. вет. наук, доцент кафедры «Болезни животных и ветеринарно-санитарная экспертиза, Саратовский государственный аграрный университет имени Н.И. Вавилова. Россия.

410005, г. Саратов, ул. Соколовая, 335.

Тел.: (8452) 69-25-32.

Панков Иван Юрьевич, ветеринарный врачспециалист по рыночным испытаниям, ООО «НитаФарм». Россия.

410010, г. Саратов, ул. Осипова, 1.

Тел.: (8452) 33-86-00.

Брюханова Анастасия Андреевна, студентка, Саратовский государственный аграрный университет имени Н.И. Вавилова. Россия.

410005, г. Саратов, ул. Соколовая, 335.

Тел.: (8452) 69-25-32.

Ключевые слова: хронический эндометрит; препараты «Лексофлон», «Ветбицин-3»; половая изикличность; экссудат.

\section{PREPARATION “LEXOFLON" FOR THE TREATMENT OF COWS WITH CHRONIC PURULENT-CATARRHAL ENDOMETRITIS}

Semivolos Aleksander Mephodyevich, Doctor of Veterinary Sciences, Professor of the chair "Animal Diseases and Veterinarian and Sanitarian Expertise”, Saratov State Agrarian University named after N.I. Vavilov. Russia.

Kashkovskaya Lyudmila Mikhaylovna, Candidate of Veterinary Sciences, Associate Professor of the chair "Animal Diseases and Veterinarian and Sanitarian Expertise", Saratov State Agrarian University named after N.I. Vavilov. Russia.

Pankov Ivan Yurievich, LeadingSpecialist, ZAO "NitaFarm”. Russia.
Bryukhanova Anastasiya Andreevna, Student, Saratov State Agrarian University named after N.I. Vavilov. Russia.

Keywords: chronic endometritis; preparation "Lexoflon", "Vetbitsin-3"; sexual cyclicity; exudate.

The results of studies on the application of the preparation "Lexoflon" to treat cows with chronic purulent-catarrhal endometritis are given. The most effective for animals was intramuscular administration of the drug at a dose of $1 \mathrm{ml} / 10 \mathrm{~kg}$ of body weight with an interval of 3 days. Clinical recovery occurred after $8.0 \pm 0.18$ days, the frequency of using the preparation per 1 head was $2.5 \pm 0.12$. 